JEL:Q10

\author{
Руденко Микола Вікторович, \\ асистент кафедри менеджменту, \\ Білочерківський начіональний аграрний університет, \\ м. Біла Церква, Україна \\ e-mail:nvrudenko@i.ua
}

\title{
РОЗВИТОК ЖИТЛОВОЇ ІНФРАСТРУКТУРИ СІЛЬСЬКИХ ТЕРИТОРІЙ НА ОСНОВІ ДЕРЖАВНО-ПІДПРИЕМНИЦЬКОГО ПАРТНЕРСТВА
}

\begin{abstract}
Анотація. У статті розглянуто питання розвитку житлової інфраструктури сільських територій. За умови сучасної тенденції урбанізації та переселення мешканців сільських територій до міст, сочіальний розвиток сільських територій, зокрема житлового господарства, набувають актуальності у теперішньому реформуванню економіки країни. Агропромисловий комплекс країни розвивається прогресуючими темпами, проте розвиток сочіальної інфраструктури сільських територій значно відстає. За результатами проведеного аналізу зроблено висновки про те, що темпи житлового будівництва та введення в експлуатацію житла у міських поселеннях у 2,5 рази перевищують темпи житлового будівництва у сільській місчевості. Кількість збудованих квартир у сільській місцевості за період 201-2017 рр. зросла на 3,85\%. Загальна житлова площа прийнятого в експлуатацію житла у міських поселеннях у 2017 р. у 2,48 рази перевищила загальну житлову площу у сільських поселеннях. Кількість збудованих квартир у міських поселеннях у 2017 р. у 3,67 рази перевищила кількість збудованих квартир у сільській місиевості.

У Київській області розташовано 6718 будинків сільського, селищного та відомчого житлового фонду, з яких $355 \epsilon$ об'єднаннями співвласників багатоквартирних будинків. Значний фізичний знос тепломереж, водопостачальних мереж та мереж водовідведення є проблемою Київського регіону. Для вирішення цієї проблеми потрібні значні фінансові інвестиції, які держава не може виділити у повному обсязі. Доцільно рекомендувати поступове вирішення проблеми відновлення та реконструкції житлової інфраструктури сільських територій за рахунок впровадження механізму державно-підприємницького партнерства, що сприятиме зменшенню диспропориій у житлових умовах та споживанні послуг між сільським та міським населенням. Враховуючи відсутність достатнього досвіду України у застосування механізму державно-підприємницького партнерства та наявність достатньо повної законодавчої бази для його реалізачії, рекомендовано на початковому етапі оформлювати відносини співпраці державного та приватного секторів на основі договорів оренди.
\end{abstract}

Ключові слова: Україна; житловий фонд; стан; розвиток; інновачії; законодавство; регулювання; нормативно-правові акти; ефективність.

DOl:http://doi.org/10.32750/2018-0208

(๑) М.В. Руденко, 2018

\section{ВСТУП}

Постановка проблеми. Розвиток та ефективне функціонування житлово-комунальної інфраструктури сільських територій відіграє значну роль у розвитку національної економіки країни та $є$ значним чинником у забезпеченні соціальної безпеки країни. Сучасний стан житлово-комунальної інфраструктури в Україні характеризується низькою ефективністю діяльності, дефіцитом бюджетних коштів на їі розвиток, повільним узгодженням нормативних актів, повільним впровадженням інновацій, зокрема ресурсозберігаючих технологій, низьким рівнем демонополізації та створення конкурентного середовища. Зволікання із реформуванням житлово-комунальної інфраструктури 
приводить до погіршення іï стану та розвитку кризової ситуації в країні. Все це вимагає пошуку нових ідей в галузі державно-підприємницького партнерства розвитку житлово-комунальної інфраструктури сільських територій.

Аналіз останніх досліджень і публікацій. Проблемам соціально-економічного розвитку інфраструктури сільських територій приділяли увагу у своїх працях наступні вчені: 3. Варналій, В.П. Рябоконь, Л.А. Рарок, Л.І. Воркун, Л.К. Демкович, В.С. Коробка, Т.Г. Пенцак, В. Мельник, О. Погрещук, Т.П.Саблук, М.Й.Малік, О.М.Кропивко, О.Г.Булавка та інші. Попри грунтовні та багатоаспектні дослідження науковців у сфері розвитку житлово-комунальної інфраструктури дотепер не існує єдності наукових поглядів, що обумовлює необхідність дослідження даного питання та розробки практичних рекомендацій саме для сільських територій.

Мета статті полягає у дослідженні сучасного стану житлової інфраструктури сільських територій та визначення напрямів розв'язання проблеми іiі подальшого розвитку на основі державно-підприємницького партнерства.

\section{РЕЗУЛЬТАТИ ДОСЛІДЖЕННЯ}

Соціальна інфраструктуру, зокрема житлове господарство, є одним із найбільш значущих внутрішніх чинників рівня життя мешканців сільських територій. Стан соціального розвитку сільських територій тісно пов'язаний із агропромисловим виробництвом на цих територіях. Але існує і зворотній зв'язок: чим вище стан соціального розвитку сільської території, тим доцільніше будувати там агропідприємства.

За сьогоднішніх умов економічного розвитку нашої країни більшість сільських територій характеризуються низьким рівнем соціально-економічного розвитку, особливо у сфері житлового господарства. Сучасний процес урбанізації сприяє переселенню працездатного населення із сільської місцевості до міст, що підвищує попит на житло у містах та знижує попит на житло у селах. Житловий фонд у містах має тенденцію до зростання за рахунок нового будівництва та реконструкції зношеного житлового фонду. Житловий фонд у сільській місцевості розвивається більш повільними темпами (табл. 1).

Таблиия 1

ДИНАМІКА ТЕМПІВ РОЗВИТКУ ЖИТЛОВОГО ФОНДУ УКРАЇНИ ЗА РАХУНОК ПРИЙНЯТОГО В ЕКСПЛУАТАЦІЮ ЖИТЛА ЗА ПЕРІОД 2013-2017 pp.

\begin{tabular}{|c|c|c|c|c|c|c|}
\hline Показник & 2013 & $2014^{1}$ & $2015^{1}$ & $2016^{1}$ & $2017^{1}$ & $\begin{array}{c}\text { Відхилення } \\
\text { даних } 2017 \\
\text { від 2013, \% }\end{array}$ \\
\hline $\begin{array}{l}\text { Прийняття в експлуатацію житла } \\
\text { по Україні - усього, тис. м² }\end{array}$ & 9949 & 9741 & 11044 & 9367 & 10206 & 2,58 \\
\hline $\begin{array}{l}\text { У т.ч. } \\
\text { - у міських поселеннях, тис. м² }\end{array}$ & 6685 & 6645 & 7465 & 6503 & 7274 & 8,81 \\
\hline - у сільській місцевості, тис. м² & 3264 & 3096 & 3579 & 2864 & 2932 & $-10,17$ \\
\hline Кількість збудованих квартир, тис. & 93 & 105 & 120 & 113 & 126 & 35,48 \\
\hline $\begin{array}{l}\text { Кількість збудованих квартир } \\
\text { у міських поселеннях, тис. }\end{array}$ & 67 & 77 & 89 & 85 & 99 & 47,76 \\
\hline $\begin{array}{l}\text { Кількість збудованих квартир } \\
\text { у сільській місцевості, тис. }\end{array}$ & 26 & 28 & 31 & 28 & 27 & 3,85 \\
\hline
\end{tabular}

Джерело: складено автором за даними [ ]

Динаміка темпів прийняття в експлуатацію житла за рахунок нового будівництва за період 2013-2017 рр. по Україні в цілому має позитивну тенденцію до зростання. Темпи приросту житлового фонду різні: в міських поселеннях житловий фонд за досліджуваний період збільшився на 8,8 \%, проте у сільській місцевості обсяги введення в експлуатацію житлового фонду зменшились на $10,17 \%$. Кількість збудованих квартир в цілому по Україні за період

\footnotetext{
${ }^{1}$ Офіційні дані за 2014-2017 рр. наведено без урахування тимчасово окупованої території Автономної Республіки Крим і м. Севастополя.
} 
2013-2017 pр. зросла на 35,48 \%, у тому числі у міських поселеннях - на 47,76 \%, у сільській місцевості - на 3,85 \%. Загальна житлова площа прийнятого в експлуатацію житла у міських поселеннях у 2017 р. у 2,48 рази перевищила загальну житлову площу у сільських поселеннях. Кількість збудованих квартир у міських поселеннях у 2017 р. у 3,67 рази перевищила кількість збудованих квартир у сільській місцевості. Таким чином, можна зробити висновок, що темпи житлового будівництва та введення в експлуатацію житла у міських поселеннях у 2,5 рази перевищують темпи житлового будівництва у сільській місцевості. За даними Державної служби статистики України люди, що проживають у сільській місцевості мають гірші житлові умови, ніж люди, які мешкають у міських поселеннях у 2017 р.

У Київській області загальна площа житлових будинків та квартир в сільській місцевості складає 13,09 млн. м², загальною кількістю 6718 будинків сільського, селищного та відомчого житлового фонду. На території Київської області створено та функціонує 355 об'єднань співвласників багатоквартирних будинків. Загальна протяжність водопровідних мереж складає 5,112,98 км. Фізичний знос водопостачальних мереж та мереж водовідведення $\epsilon$ проблемою регіону. Понад 40 \% мереж водовідведення експлуатується понад 40 років і має значний фізичний знос, більше $35,0 \%$ мереж перебуває в аварійному стані. За статистичними даними благоустрій житлового фонду сільських території часто має незадовільний стан. За проведеними обстеженнями 39,0 \% квартир, які розташовано у селах, не мають центрального опалення, 40, 0 \% квартир не мають водопроводу, 45,0 \% квартир не мають природного газу [1]. Багато будинків у сільській місцевості використовуються сезонно, частина з них є повністю покинутими.

Київська область належить до енергонасичених регіонів. На території Київщини розташовано енергогенеруючі підприємства: Трипільська ТЕС, Білоцерківська ТЕЦ, каскад Київських ГЕС, малі гідроелектростанції. В Київській області працює 1409 енергогенеруючих підприємств, з них 225 - на альтернативних видах палива. Підприємства енергетики Київської області виробляють 7 млрд. кВт* год/рік електроенергії, що перевищує обсяги ії споживання на 1,7 млрд. кВт год/рік [5]. Повне забезпечення споживачів електричною енергією $є$ позитивною рисою економічного розвитку Київської області.

Розвиток сільських територій пов'язаний не тільки із наявністю та вдосконаленням житлового фонду, а також із наявністю та розвитком іншої соціальної інфраструктури. До соціальної інфраструктури відносять заклади освіти, культури, охорони здоров'я, служби побуту, транспорту і зв'язку у частині, пов'язаній з обслуговуванням населення, інші заклади невиробничої сфери та торгівлі. Система освіти в Україні є комплексним поєднанням у собі навчання та виховання. Першою ланкою системи освіти є дошкільне виховання, другою - навчання в загально освітніх школах або гімназіях. У сільській місцевості Київської області працюють 571 загальноосвітніх навчальних закладів. Потреби населення не повною мірою задоволені існуючою мережею загальноосвітніх шкіл. За останні 9 років у сільській місцевості простежується тенденція до скорочення кількості як загальноосвітніх шкіл так і дитячих дошкільних закладів. Крупні сільські населені пункти кращі забезпечені дитячими дошкільними закладами. В останні роки у селах майже згорнута служба надання населенню побутових послуг. Відсутність достатньої кількості об’єктів соціальної інфраструктури та знижена можливість знайти постійну роботу спонукає молодь переїздити до міста. Зниження потенціалу соціальної та житлової інфраструктури сільських територій приводить до зменшення кількості сільського населення та сприяє процесу урбанізації в країні.

Важливе значення у розвитку житлової інфраструктури сільських територій має збільшення обсягу житлового будівництва та газифікація сіл. Вирішення житлової проблеми впливає на демографічну ситуацію та закріплення населення молодого віку на селі. Газифікація сіл є одним із пріоритетних завдань розвитку інфраструктури, так як вирішується не тільки питання покращення побутових умов мешканців сіл, а й питання опалення житлових будинків. Найкращий стан щодо рівня газифікації сіл маж Київська область, в якій на початок 2019 р. газифіковано 98 \% сільських будинків та квартир [1].

Враховуючи сучасні тенденції щодо утворення місцевих територіальних громад змінюється система фінансування закладів соціальної інфраструктури. Сучасний стан соціальної інфраструктури в сільській місцевості значно потерпає від хронічної нестачі фінансування. Більшість керівників підприємств, які розташовані у сільській місцевості або фермерів, які орендують землю, не зацікавлені у вкладанні грошей у розвиток соціальної сфери з різних причин. У місцевих органів влади немає можливості достатнього фінансування розвитку соціальної інфраструктури у сільській місцевості за рахунок обмеженості бюджетів. Із за відсут- 
ності достатнього фінансування соціальна інфраструктура в сільській місцевості руйнується, а люди пересіяються до міст. Починаючи із 2005 року в країні припинили існування 962 сіла, а в 369 сілах повністю відсутнє населення, проте вони ще не зняті із обліку [1]. Реформуючи економіку країни потрібно більше уваги приділити розвитку сільських територій. Враховуючи важливість соціальної інфраструктури i, зокрема, житлової інфраструктури, необхідно знаходити оптимальні джерела фінансування, розбудові та відродження сільський територій.

Одним із шляхів фінансування розвитку об’єктів соціальної інфраструктури у сільській місцевості $€$ запуск механізму державно-підприємницького партнерства. До критичних секторів соціальної інфраструктури сільських територій відносяться: централізоване теплопостачання, водопостачання та водовідведення. Централізоване теплопостачання мають 2/3 житлових будинків України. Фізичний та моральний знос основних фондів теплопостачальних мереж приводять до втрат в мережах генерації, комунікації та кінцевого споживання до $60 \%$. Обсяги споживання тепла через централізоване теплопостачання в Україні в декілька разів перевищують аналогічні обсяги в країнах Європи. За даними статистики тільки 3\% житлових багатоквартирних будинків Києва обладнано сучасними приладами обліку тепла. Багато житлових будинків в Україні не мають приладів обліку та регулювання тепла, тому споживачі не можуть контролювати фактичний стан споживання теплоенергії, а підприємці не мають стимулу щодо скорочення втрат тепла у мережах. Опалення вважається соціальним благом, тому регулювання тарифів у цій сфері повинно більше контролюватися державою. Фінансові проблеми сектору теплоенергетики $є$ комплексними. Інвестиції, які залучаються у сферу теплоенергетики не завжди працюють ефективно. Приватні підприємці, які готові вкладати приватний капітал у сферу теплоенергетики, зіштовхуються із певними законодавчими та адміністративними бар'єрами. Системи водопостачання та водовідведення також потребують значних інвестицій. Обсяг яких значно перевищує обсяги місцевих бюджетів та донорський організацій. Відповідно до чинного законодавства України не підлягають приватизації об’єкти інженерної інфраструктури по благоустрою міст та сіл, до яких також відносяться об'єкти водопостачання та водовідведення, постачання газу та тепла. Тому державно-підприємницьке партнерство можливо тільки за умови концесії чи оренди приватним сектором об'єктів комунальної власності. Використовуючи досвід європейських країн у сфері державно-підприємницького партнерства у галузі житлово-комунальної інфраструктури Україна зробила суттєві кроки вперед. В Україні створена достатньо повна законодавча база реалізації проектів на основі державно-підприємницького партнерства. Суттєвим недоліком $€$ відсутність найбільш прийнятної інституційної структури, а саме, органів виконавчої влади, які б забезпечували б на достатньо прозорому рівні експертизу та відбір проектів, контроль за здійсненням інвестування та гарантування приватних інвестицій, консалтингові послуги тощо. У вирішенні цієї проблеми Україні доцільно спиратися на досвід інших країн, які мають успіх у розвитку соціальних проектів за рахунок існуючого в цих країнах механізму публічно-приватного партнерства. До успішного застосування механізму державно-підприємницького партнерства в Україні важливо також формувати громадську думку щодо передачі частини контролюючих функцій у сфері житлової інфраструктури підприємствам приватного сектору.

\section{ВИСНОВКИ ТА ПЕРСПЕКТИВИ ПОДАЛЬШИХ ДОСЛІДЖЕНЬ}

Розвиток житлової інфраструктури за рахунок державно-підприємницького партнерства сприятиме зменшенню диспропорцій у житлових умовах та споживанні послуг між сільським та міським населенням. За законодавством України існує достатня правова база для залучення інвестицій у житловий сектор сільських територій через механізм державно-підприємницького партнерства. Використання світового досвіду розвитку житлового інфраструктури сприятиме впровадженню та використанню нових технологій для будівництва, відновлення та покращення функціонування об'єктів житлового сектору економіки. Застосування механізму державно-підприємницького партнерства дозволить державі отримати значну вигоду від залучення приватного капіталу у сферу житлової інфраструктури сільських територій і сприятиме розвитку цих територій. Зважаючи на недостатність досвіду у застосуванні механізму державно-підприємницького партнерства для розвитку сільських територій, доцільно рекомендувати оформлювати відносини співпраці державного та приватного секторів на основі договорів оренди, як найбільш ефективного для початкових етапів. Треба зауважити, що державно-підприємницького партнерства як механізм реалізації соціальних проектів може бути дуже корисним для реалізації цих проектів за умови обмеженості дер- 
жавних фінансових ресурсів, проте він $є$ досить складним у реалізації інструментом. Не варто розраховувати, що застосування механізму державно-підприємницького партнерства буде ефективним без стратегічних програм розвитку сільських територій, які $є$ пріоритетними у вирішенні питання створення ефективної житлової інфраструктури на селі.

\title{
СПИСОК ВИКОРИСТАНИХ ДЖЕРЕЛ
}

1. Офіційний сайт Державної служби статистики України. Статистична інформація. Діяльність будівельних підприємств. URL: www.ukrstat.gov.ua (дата звернення 2.12.2018).

2. Про схвалення Концепції розвитку сільських територій: Розпорядження кабінету Міністрів України. URL: https://zakon.rada.gov.ua/go/995-2015-р (дата звернення 2.12.2018).

3. Господарський кодекс України. URL: http://zakon.rada.gov.ua/ (дата звернення 4.12.2018).

4. Коробка С.В., Пенцак Т.Г. Проблеми соціально-економічного розвитку сільських територій в Україні. Науковий вісник ЛНУВМБТ імені С.3. Гжицького. 2017. т 19. № 76. С. 67-71.

5. Стратегія розвитку Київської області на період до 2020 року. Рішення Київської обласної ради від 04.12.2014 № 856-44-VI. URL: https://www.kyivregioneconomy.com/strategiya-kiyivskoyioblasti-2020

\section{РАЗВИТИЕ ЖИЛИЩНОЙ ИНФРАСТРУКТУРЫ СЕЛЬСКИХ ТЕРИТОРИЙ НА ОСНОВЕ ГОСУДАРСТВЕННО-ПРЕДПРИНИМАТЕЛЬСЬКОГО ПАРТНЕРСТВА}

\author{
Руденко Николай Викторович, \\ Ассистент кафедры менеджмента, \\ Белоцерковский национальный аграрный университет, \\ г. Белая Церковь, Украина \\ e-mail:nvrudenko@i.ua
}

\begin{abstract}
Аннотация. В статье рассмотрены вопросы развития жилищной инфраструктуры сельскихтерриторий. При современной тенденции урбанизации и переселения жителей сельских территорий в города, социальное развитие сельских территорий, в частности жилищного хозяйства, приобретают актуальность в современном реформировании экономики страны. Агропромышленный комплекс страны развивается прогрессирующими темпами, однако развитие социальной инфраструктуры сельских территорий значительно отстает. По результатам проведенного анализа сделаны выводы о том, что темпы жилищного строительства и ввода в эксплуатацию жилья в городах в 2,5 раза превышают темпы жилищного строительства в сельской местности. Количество построенных квартир в сельской местности за период 2013-2017 г2. выросло на 3,85 \%. Общая жилая площадь принятого в эксплуатацию жилья в городах в 2017 г. в 2,48 раза превысила общую жилую площадь в селах. Количество построенных квартир в городах в 2017 г. в 3,67 раза превысило количество построенных квартир в сельской местности.

В Киевской области расположено 6718 домов сельского, поселкового и ведомственного жилого фонда, из которых 355 являются объединениями совладельчев многоквартирных домов. Значительный физический износ теплосетей, водопроводных сетей и сетей водоотведения является проблемой Киевского региона. Для решения этой проблемы требуются значительные финансовые инвестиции, которые государство не может выделить в полном объеме. Целесообразно рекомендовать постепенное решение проблемы восстановления и реконструкции жилой инфраструктуры сельских территорий за счет внедрения механизма государственно-предпринимательского партнерства, который будет способствовать снижению диспропорций в жилищных условиях и потреблении услуг между сельским и городским населением. Учитывая отсутствие достаточного опыта Украины в применения механизма государственно-предпринимательского партнерства и наличие достаточно полной законодательной базы для его реализации, рекомендуется на начальном этапе оформлять отношения сотрудничества государственного и частного секторов на основе договоров аренды.
\end{abstract}

Ключевые слова: Украина; жилой фонд; состояние; развитие; инновачии; законодательство; регулирование; нормативно-правовые акты; эффективность. 


\title{
DEVELOPMENT OF HOUSING INFRASTRUCTURE OF AGRICULTURAL TERRITORIES BASED ON THE STATE-BUSINESS PARTNERSHIP
}

\author{
Nykolai Rudenko, \\ Assistant of the Department of Management, \\ Belotserkovsky National Agrarian University, \\ Belaya Tserkov, Ukraine \\ e-mail:nvrudenko@i.ua
}

\begin{abstract}
The article deals with the issue of development of housing infrastructure of rural areas. Given the current trend of urbanization and resettlement of rural inhabitants to cities, social development of rural territories, in particular housing, becomes relevant in the light of the current reform of the economy of Ukraine. Agro-industrial complex of the country is developing at a progressive pace. At the same time the development of social infrastructure of rural areas is significantly lagging behind. According to the results of one of the analyses it has been concluded that the pace of residential construction and commissioning of housing in urban settlements by 2,5 times exceeds the rates of housing construction in rural areas. Number of built apartments in the countryside for the period 2013-2017 grew only by 3,85\%.

The total living area of residential housing commissioned in urban areas in 2017 exceeded the total living space in rural settlements by 2,48 times. Number of flats built in urban settlements in 2017 by 3,67 times exceeded the number of apartments constructed in rural areas. In the Kyiv region there are 6718 houses of village, settlement and departmental housing stock, of which 355 belong to the associations of co-owners of apartment houses. Significant physical wear and tear of the heating systems, water supply networks and drainage networks is a problem of the Kyiv region. To solve this problem, substantial financial investments are needed, which the state can not allocate in full. Under existing circumstances, it is advisable to recommend a gradual solution to the problem of the renovation and reconstruction of residential infrastructure of rural areas through the introduction of the mechanism of state-entrepreneurial partnership, which will help to reduce disproportions in living conditions and consumption of services between rural and urban population. Taking into account the lack of sufficient experience of Ukraine in application of the mechanism of state-entrepreneurial partnership and at the same time the availability of quite complete legislative framework for its implementation in the country, it is recommended that at the initial stage, the relations between the state and private sectors should be formalized on the basis of lease agreements.
\end{abstract}

Key words: Ukraine; housing stock; state; development; innovation; legislation; regulation; legal and normative acts; efficiency.

\section{REFERENCES (TRANSLATED AND TRANSLITERATED)}

1. Official site of the State Statistics Service of Ukraine. Statistical information. Activities of construction enterprises. (n.d.). Retrieved December 01, 2018, from http://www.ukrstat.gov.ua/operativ/menu/ menu_u/bud.htm

2. Order of the Cabinet of Ministers of Ukraine. On Approval of the Concept of Rural Development. (2015, September 23). Retrieved December 02, 2018, from https://zakon.rada.gov.ua/go/995-2015-p 3. Economic Code of Ukraine. (2003). Retrieved December 04, 2018, from https://zakon.rada.gov.ua/ laws/show/436-15

4. Korobka, S., \& Pentsak, T. (2017). Problemy Sotsialno-Ekonomichnoho Rozvytku Silskykh Terytorii V Ukraini. Naukovyi Visnyk LNUVMBT Imeni S.Z. Gzhytskoho,19(76), 67-71. Retrieved December 3, 2018.

5. The decision of the Kyiv Regional Council. Strategy of development of the Kyiv region for the period till 2020 № 856-44-VI. (2014, December 04). Retrieved from https://www.kyivregioneconomy.com/ strategiya-kiyivskoyi-oblasti-2020 